\title{
Spatial and Temporal Regeneration Dynamics in Ceriops tagal ( Perr.) C.B. Rob. (Rhizophoraceae) Mangrove Forests in Kenya
}

\author{
J.O. Bosire ${ }^{1,3}$, J.G. Kairo², J. Kazungu' ${ }^{1}$, N. Koedam ${ }^{3}$, F. Dahdouh-Guebas ${ }^{2,4}$ \\ ${ }^{1}$ Kenya Marine and Fisheries Research Institute (KMFRI), P. O. Box 81651, Mombasa, Kenya; ${ }^{2}$ Biocomplexity \\ Research Team; ${ }^{3}$ Laboratory of General Botany and Nature Management, Mangrove Management Group, \\ Vrije Universteit Brussel, Pleinlaan 2, B-1050 Brussels, Belgium; ${ }^{4}$ Biocomplexity Research Focus c/o \\ Département de Biologie des Organismes, Université Libre de Bruxelles, ULB - Campus du Solbosch, CP 169, \\ Avenue Franklin D. Roosevelt 50, B-1050 Bruxelles, Belgium
}

Keywords: Seedling growth, recruitment, natural regeneration, Ceriops tagal, Gazi

\begin{abstract}
Mangrove forests consist of a mosaic of tree cohorts, each having a regeneration history that depends on episodic recruitment of seedlings based on the availability of a "regeneration niche". The aim of this study was to assess seedling population structure in Ceriops tagal natural monospecific stands and one eight-year old reforested stand at Gazi Bay, Kenya, to determine performance in terms of growth and survival over a period of two years. Four natural monospecific stands (two on the western creek designated as site 1 and 2, and two on the eastern creek designated as site 4 and 5) were identified with the reforested stand (on the eastern creek) as site 3 . The vegetation structure of these stands and natural regeneration were assessed by Linear Regeneration Sampling. Regeneration Class I (RCI) seedlings of known age were tagged and their growth parameters (diameter, height, leaf production and number of nodes) and survival rates monitored for a period of two years. The reforested stand had the same basal area $\left(2.2 \pm 0.1 \mathrm{~m}^{2}\right.$ ha $\left.^{-1}\right)$ as site $1\left(2.1 \pm 0.1 \mathrm{~m}^{2} \mathrm{ha}^{-1}\right)$, and the former's mean height was also similar to that of western creek sites (1 and 2), but lower than the eastern creek sites (4 and 5). The western creek sites had the highest seedling mortality ( $61 \%$ for both) and lowest growth rates recorded over the two year period compared to a mortality of $45 \%$ for the eastern sites. An analysis of seedling growth over the two years as a function of measured environmental factors showed a weak interaction, with height above datum (HAD) and canopy cover showing the highest correlation of only $30 \%$. The high mortality on the western creek sites may be attributed to harsh environmental conditions due to the limited expanse of the intertidal area of the western creek mangroves compounded with anthropogenic pressure due to its proximity to human settlements. Overall, $C$. tagal forests at Gazi Bay seem to be more vulnerable to environmental stress because they occur at the upper intertidal area, which limits their long-term structural development. Of the four species common at Gazi, C. tagal is the least structurally developed with very low basal areas and mean heights, which are both important determinants of wood quality. These upper-shore forests therefore require management approaches distinct from those of other species to ensure that their natural regeneration and overall structural development are not unsustainably compromised.
\end{abstract}

\section{INTRODUCTION}

Natural regeneration is significant for the restocking of forest stands and its potential is a critical factor in the formulation of forest management plans. Seedling survivorship principally drives population growth (Burns \& Ogden, 1985) and thus determines the quality of the crop and productivity of forest 
stands (Srivasatava \& Bal, 1984). Studies on seedling demography are lacking for Kenyan mangroves, creating a major gap for the planning of rotational cycles, or best practice guidelines for sustainable forestry production. Mangrove seedling demographic studies are also limited globally (Ellison \& Farnsworth, 1993; 1996; Clarke \& Allaway, 1993; Osunkonya \& Creese, 1997).

Mangrove forests generally consist of a mosaic of tree cohorts, each having a regeneration history that depends on episodic recruitment of seedlings (Clarke, 1995). The basic regeneration units in mangrove forests (especially for the Rhizophoraceae family) are propagules, which establish regularly because they contain precociously developed embryos whose recruitment into older classes depends on the episodic availability of a "regeneration niche" (Pearson et al., 2003). The regeneration niche is determined by canopy gap creation and prevailing environmental factors. Coupled with this regeneration niche are interspecific factors (primarily competition) and environmental filtering, which drive the regeneration process. The most commonly reported environmental factors influencing regeneration include predation (Smith, [1987; Dahdouh-Guebas et al, 1997, 1998; Lee, 1998; Clarke \& Kerrigan, 2002; Bosire et al., 2005), physical conditions e.g. local hydrodynamics, inundation regimes, geomorphology, salinity, irradiance, soil redox potential, pore water sulphide concentration, and others (McKee, 1993; Matthijs et al., 1999; Ball, 2002; Thampanya et al., 2002; Bosire et al., 2003). These factors operate at different scales in different mangrove sites due to varying physical settings, including stand-specific management regimes. Anthropogenic pressure may also influence natural regeneration and thus determine stand structure (Dahdouh-Guebas et al., 2004, 2005) through either selective extraction, or other impacts resulting in cryptic or general degradation.

Ceriops tagal (Perr.) C.B. Rob. is one of the dominant mangrove species in Kenya ranked second to Rhizophora mucronata Lamk. in terms of its economic importance (Kairo et al., 2002). The local people utilise its wood for house construction, fishing stakes, fence posts, tannin extraction and as a source of high quality fuel-wood (UNEP, 1998; Dahdouh-Guebas et al., 2000). The species is widely distributed and normally grows in the upper intertidal area of inundation class IV and V, according toWatson (1928).

The main objective of this study was to assess spatial seedling growth and survival rates at the post-cotyledonary phase i.e. after propagule establishment, in C. tagal monospecific stands at Gazi Bay, Kenya to provide data, which may aid the management of this economically important mangrove species.

\section{MATERIALS AND METHODS}

Structure, regeneration and demography

Two natural stands of Ceriops tagal were identified; one on the western creek (site 1 and 2) and the other on the eastern creek (site 4 and 5) of Gazi Bay (Fig 1). One reforested eight-year old stand was also incorporated in the study. A transect, running parallel to the shoreline, was made for each site and five permanent quadrats of $5 \times 5 \mathrm{~m}$, randomly marked-out. Data on diameter at breast height (dbh) was measured at $50 \mathrm{~cm}$ above the ground (because C. tagal at Gazi are generally stunted) for all trees over $2.5 \mathrm{~cm}$ diameter. Height and density data of trees were collected using the phyto-sociological methods of Cintrón and Schaeffer-Novelli (1984). All trees with diameter less than $2.5 \mathrm{~cm}$ were classified as juveniles and categorised into three Regeneration Classes (RCs) based on height: RCI (height $<40 \mathrm{~cm})$, RCII $(40.5-150 \mathrm{~cm})$ and RCIII (height $>150 \mathrm{~cm}$ but diameter $<2.5 \mathrm{~cm}$ ). Cover was estimated as a percentage of the canopy covering the forest floor. Basal area was calculated from measured diameter at breast height (dbh).

To assess seedling demography in terms of population structure and spatial patterns in the $C$. tagal stands, all $\mathrm{RC} 1$ seedling (height $<40 \mathrm{~cm}$ ) in the above quadrats were uprooted (after assessing vegetation structure and natural regeneration in the plots) to allow for recruitment of individuals whose age could later be ascertained. This experimental work was conducted during the peak reproductive season of this species (Kairo, 1995), which corresponds with the long rains (April June). Bi-weekly visits were made to the stands to check for colonization by juveniles, which could be tagged for population structure studies. After three months, the RCI seedlings were tagged using 

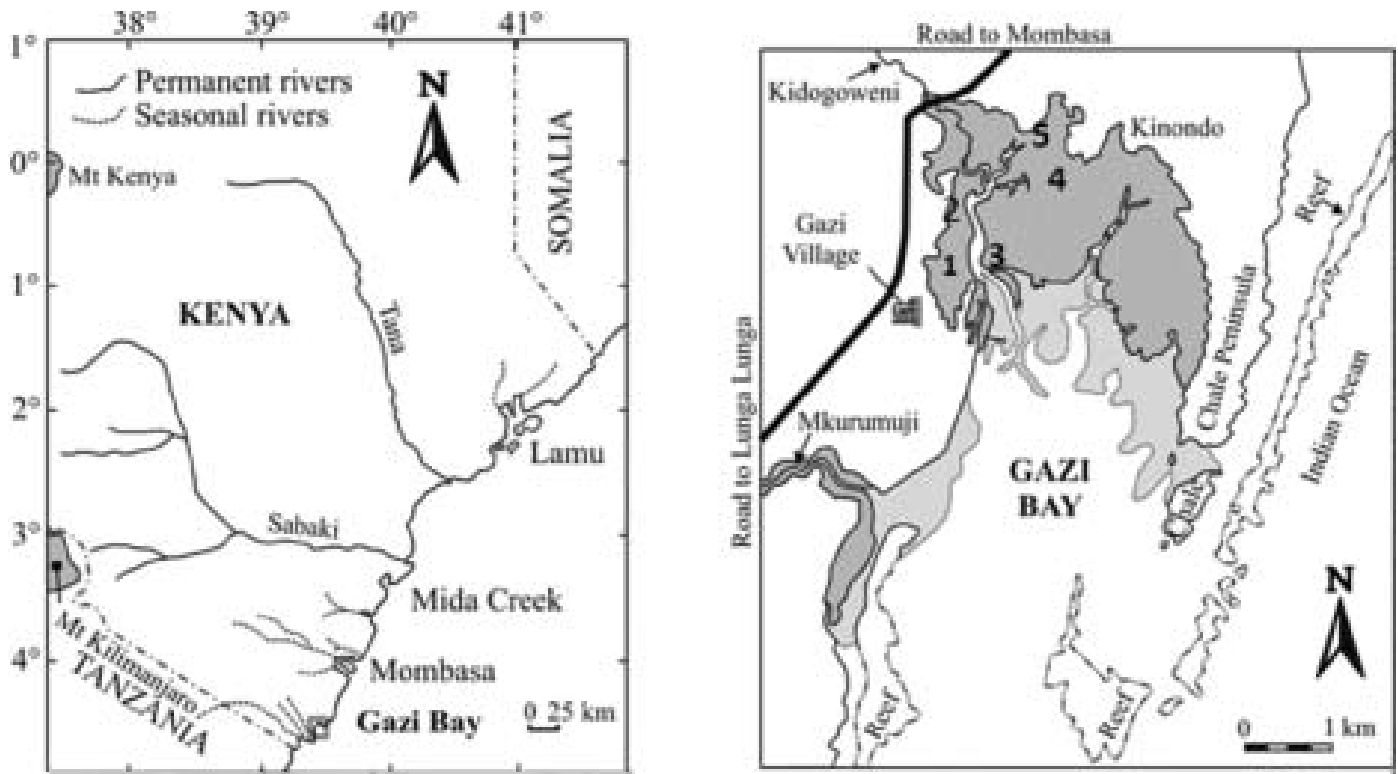

Fig. 1. Map of Gazi Bay showing the study locations as: 1 and $2=$ Western creek C. tagal natural stands, $3=$ C. tagal reforested stand, 4 and 5 = Eastern creek $C$. tagal natural stands; Mangroves, sand-flat, terrestrial vegetation and creek water

labelled dynamo tape attached with monofilament line. Monthly growth recordings, notably height, diameter, number of leaves, number of nodes, density and status of the seedling (eaten by crabs, withered, or not found) were started in August 2002 and continued until August 2004.

\section{ENVIRONMENTAL FACTORS}

In each of the permanent quadrats above, two sediment cores of diameter $4 \mathrm{~cm}$ and $10 \mathrm{~cm}$ depth were randomly taken for analysis of nutrients (PO43-, NH4+, and NO3-). Two additional cores were extracted for grain size and organic matter analysis. The pore water collecting in the holes after sediment core extraction was used to measure salinity with a refractometer. For the nutrient samples, extraction of seawater was carried out with $1 \mathrm{M} \mathrm{KCl}$ and subsequent analysis done according to Parsons et al. (1984). The extra cores were dried at $80^{\circ} \mathrm{C}$ to a constant weight to determine moisture content. A pre-determined weight of dried sediment was baked to ash at $450^{\circ} \mathrm{C}$ for 24 hours in a muffle furnace, to determine the organic matter content. About $50 \mathrm{~g}$ each of the samples dried at $80^{\circ} \mathrm{C}$ was then weighed and dry-sieved over a $65 \mu \mathrm{m}$ sieve to separate respective coarse and fine fractions.
Height above datum (HAD) of the various plots was measured using mangrove poles wrapped in dyed plotting papers. The poles were fixed in the field during one spring tide and the height of the tidal water on the poles subtracted from the specific day's tidal height (from the tidal table) to obtain the respective HADs of the various plots.

\section{Data analysis}

Data sets were log-transformed for normality and spatial and temporal comparisons analysed with single-factor ANOVA. Paired comparisons were made using Tukey's HSD test. The spatial patterns of adult trees and juveniles in the various quadrats were calculated based on Morisita's (1959) index of dispersion, as described in Greig-Smith (1983):

$$
\mathrm{I}_{\mathrm{o}}=\mathrm{q} \sum_{\mathrm{i}}^{\mathrm{q}} \frac{\mathrm{n}_{\mathrm{i}}\left(\mathrm{n}_{\mathrm{i}}-1\right)}{\mathrm{N}(\mathrm{N}-1)}
$$

Where, $q$ is the number of quadrats, ni is the number of individuals per species in the ith plot, and $\mathrm{N}$ is the total number of individuals in all q quadrats. If Io $=1$, the population is randomly dispersed and individuals have an equal probability of occupying any point in space irrespective of the position of 
others, leading to uneven distribution. If Io $>1$, the population is clumped, or under-dispersed, and individuals are more likely to survive in particular parts of the environment, and perhaps the presence of one individual gives rise to another close to it. Trees are thus closer together than expected by chance. If Io $<1$, the population is evenly/uniformly dispersed, also called over-disperson (Begon et al., 1996; Dale, 1999). Primer 5 (version 5.2.8) was used to analyse for interactions among seedling growth patterns and the measured environmental parameters using BIOENV (for all environmental factors) and BIOSTEP for a paired analysis to sort out the factors likely to most influence seedling growth (Clarke \& Gorley, 2001).

\section{RESULTS}

\section{Structural composition and regeneration}

There was an overall significant difference $(\mathrm{p}<$ 0.05 ) in adult tree density, canopy cover and basal area among the $C$. tagal sites (see Tables 1). The difference in adult tree density was contributed by the differences among sites 1 and 3, and sites 3 and 4, while differences among sites 1 and 2, 1 and 4, 2 and 3, and 3 and 4 contributed to the highly significant difference $(\mathrm{p}<0.01)$ in basal area. The reforested stand (site 3 ), though only eight years

Table 1. Basal area, density, percentage canopy cover and height (Mean $\pm \mathrm{SE})$ in $C$. tagal sites

\begin{tabular}{|c|c|c|c|c|}
\hline Site & BA m ${ }^{2} h^{-1}$ & Density ha ${ }^{-1}$ & Cover $(\%)$ & Height (m) \\
\hline 1 & $2.7 \pm 0.5$ & $1,683 \pm 268$ & 69 & $2.1 \pm 0.1$ \\
\hline 2 & $5.4 \pm 0.5$ & $2,396 \pm 154$ & 54 & $2.4 \pm 0.1$ \\
\hline 3 & $2.7 \pm 0.5$ & $3.043 \pm 512$ & 75 & $2.2 \pm 0.1$ \\
\hline 4 & $5.3 \pm 0.7$ & $1,878 \pm 259$ & 45 & $3.8 \pm 0.1$ \\
\hline 5 & $3.5 \pm 0.2$ & $1,586 \pm 74$ & 45 & $3 \pm 0.1$ \\
\hline
\end{tabular}

old, had a similar basal area and height to site 1. There was no significant difference $(p>0.05)$ in juvenile densities (all RCs combined) among the fives sites (Table 2). In order of magnitude, the western creek sites had the highest density of juveniles, followed by the eastern creek sites, with the reforested stand having the lowest density. Wide variations of juvenile density across replicates led to the lack ofsignificant differences between sites. The Morisita's indices of dispersion depicting the spatial patterns of adult trees and of juveniles and both categories combined were less than 1 , suggesting both adult trees and juveniles were evenly distributed in the stands. (Table 3 ).

\section{Seedling establishment and population structure}

Site 1 had the highest seedling density $(5,277 \pm 896$ ha-1) established at the start of the study (Fig 2), by site 3 (the reforested stand) with an initial seedling density of $3,756 \pm 656$. Site 2 , at the same western creek as site 1 , had the lowest juvenile density $(1,230 \pm 132)$ among the five sites. Though site 1 had a significantly higher initial density than sites 3 and 5, the three sites had similar densities ( $p>0.05)$ at the end of the two-year sampling period (Table 4). In terms of seedling population densities at the end of the sampling period, the five experimental sites can be grouped into two categories; those with high densities (sites 1, 3 and 5) and those with low densities (sites 2 and 4) (see Table 5). Sites 1 and 2 had the highest mortality of seedlings (61\%) in the two years (see Table 5), while 4 and 5 had the lowest mortality (45 and $44 \%$ respectively). Site 3 had an intermediate mortality of $50 \%$. Mortality of seedlings was significantly higher $(\mathrm{p}<0.05)$ in year 1 than year 2 across all sites.

Sites 1 and 2 (both at the western creek) had similar and lower height increments $(p=0.52)$ over

Table 2. Juvenile regeneration class densities (seedlings ha-1) in C. tagal sites

\begin{tabular}{lllll}
\hline Site & \multicolumn{1}{c}{ RCI } & \multicolumn{1}{c}{ RCII } & \multicolumn{1}{c}{ RCIII } & Sum \\
\hline 1 & $20,429 \pm 9,128$ & $14,958 \pm 5,979$ & $21,821 \pm 18,894$ & $57,208 \pm 22,880$ \\
2 & $12,821 \pm 7,955$ & $8,256 \pm 6,057$ & $2,979 \pm 467$ & $24,055 \pm 13,983$ \\
3 & $4,241 \pm 972$ & $453 \pm 140$ & $3,853 \pm 524$ & $8547 \pm 1,223$ \\
4 & $5,957 \pm 1,998$ & $5,018 \pm 3,863$ & $3,432 \pm 910$ & $14,407 \pm 4,408$ \\
5 & $13,760 \pm 2,840$ & $4,338 \pm 895$ & $4,371 \pm 899$ & $22,469 \pm 3,337$ \\
\hline
\end{tabular}


Table 3. Tukey's multiple paired comparisons of juvenile densities in the five sites of $\boldsymbol{C}$. tagal over the sampling period

\begin{tabular}{lcccccc}
\hline \multicolumn{2}{c}{} & \multicolumn{2}{c}{ Mean } & & & \multicolumn{2}{c}{$95 \%$ Confidence Interval } \\
(I) Site & (J) Site & $\begin{array}{c}\text { difference } \\
\text { (I-J) }\end{array}$ & Std. Error & Sig. & $\begin{array}{l}\text { Lower } \\
\text { bound }\end{array}$ & $\begin{array}{c}\text { Upper } \\
\text { bound }\end{array}$ \\
\hline 1 & & 2741 & 409 & 0.000 & 1591 & 3892 \\
& 2 & 820 & 409 & 0.276 & -330 & 1971 \\
& 3 & 2158 & 409 & 0.000 & 1008 & 3309 \\
& 4 & 1263 & 409 & 0.025 & 112 & 2413 \\
2 & 5 & -1921 & 409 & 0.000 & -3072 & -770 \\
& 3 & -583 & 409 & 0.615 & -1733 & 568 \\
& 4 & -1479 & 409 & 0.005 & -2629 & -328 \\
3 & 5 & 1338 & 409 & 0.015 & 188 & 2489 \\
& 4 & 442 & 409 & 0.815 & -708 & 1593 \\
4 & 5 & -896 & 409 & 0.198 & -2046 & 255 \\
\hline
\end{tabular}

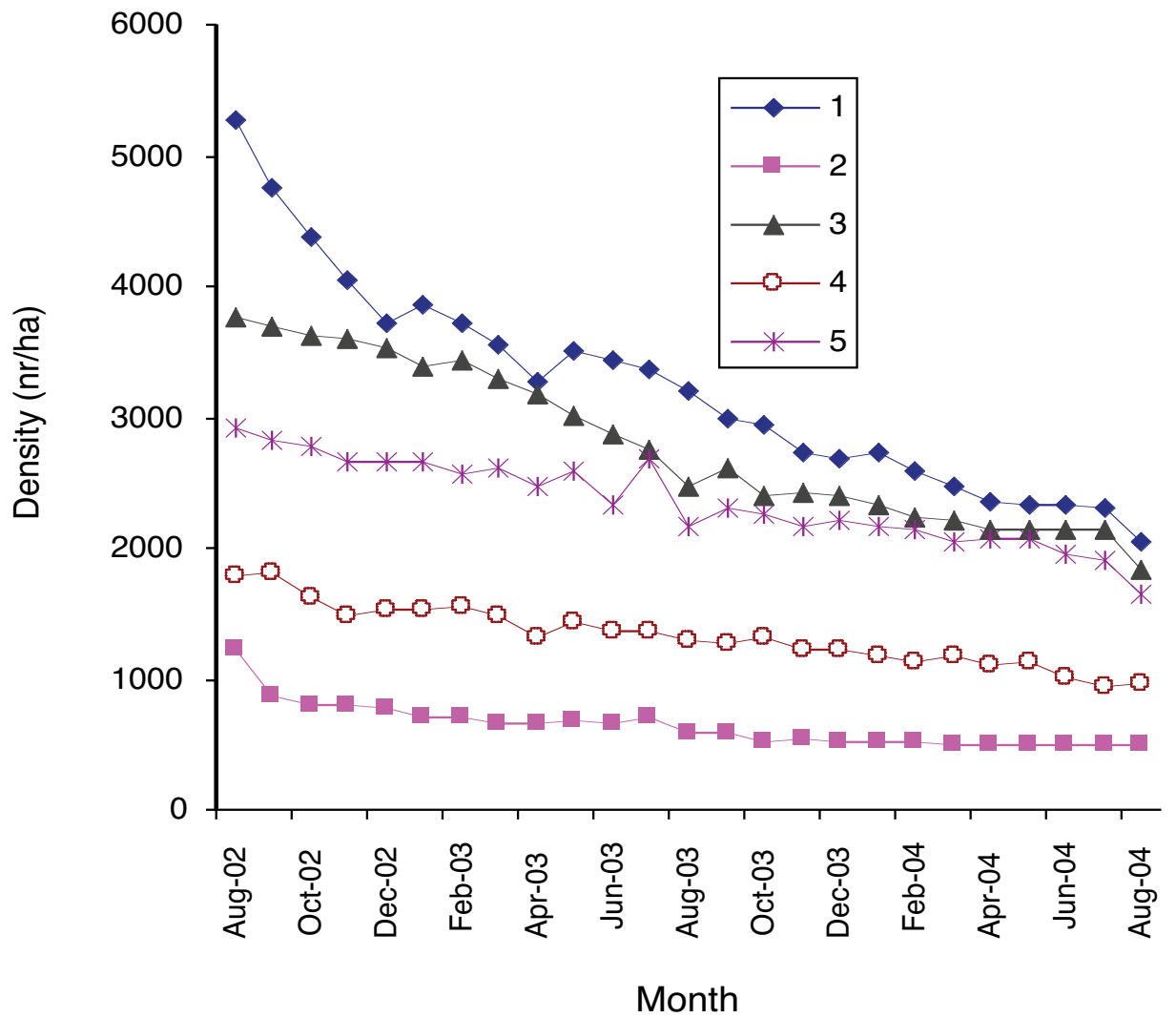

Fig 2. The density of juveniles (number/ha) in the different sites 
Table 4. Morisita's dispersion indices for adult trees (IoT), juveniles (IoJ) and adults and juveniles combined (IoTJ) for the various sites

\begin{tabular}{llll}
\hline Site & $\mathbf{I}_{\text {oT }}$ & $\mathbf{I}_{\text {oJ }}$ & $\mathbf{I}_{\text {oTJ }}$ \\
\hline 1 & 0.19 & 0.18 & 0.20 \\
2 & 0.18 & 0.47 & 0.42 \\
3 & 0.20 & 0.27 & 0.25 \\
4 & 0.19 & 0.21 & 0.22 \\
5 & 0.16 & 0.21 & 0.20 \\
\hline
\end{tabular}

(site 3), which had a net increment of $0.2 \mathrm{~cm}$ suggesting overall very low growth rates. The sites in the eastern creek (4 and 5) had higher and similar diameter than those in the western creek (sites 1 and 2). The reforested stand had similar diameter increment as the western creek sites ( $p>0.05)$.

Leaf emergence (and loss) varied over sites and yearsTo obtain the total number of leaves (leaves and nodes) emerging during the sampling

Table 5. Initial seedling density (D0), density after 1 year (D1) and after 2 years (D2) with percentage survival of seedlings at year 1 and 2 (\% SY1 and \% SY2 respectively). Seedling mortalities in percentage in year 1 (MY1), year 2 (MY2) and total mortality (TM) over the two yr are also shown

\begin{tabular}{lllllllll}
\hline Site & $\mathbf{D}_{\mathbf{0}}$ & $\mathbf{D}_{\mathbf{1}}$ & $\mathbf{D}_{\mathbf{2}}$ & $\mathbf{\%} \mathbf{S Y 1}$ & $\mathbf{\% S ~ Y 2}$ & $\mathbf{\%} \mathbf{M Y 1}$ & $\boldsymbol{\%} \mathbf{M Y 2}$ & $\mathbf{T M}$ \\
\hline 1 & 5277 & 3205 & 2040 & 61 & 39 & 39 & 22 & $\mathbf{6 1}$ \\
2 & 1230 & 583 & 486 & 47 & 39 & 53 & 8 & $\mathbf{6 1}$ \\
3 & 3756 & 2461 & 1845 & 66 & 49 & 34 & 16 & $\mathbf{5 0}$ \\
4 & 1781 & 1295 & 971 & 73 & 55 & 27 & 18 & $\mathbf{4 5}$ \\
5 & 2914 & 2169 & 1651 & 74 & 57 & 26 & 18 & $\mathbf{4 4}$ \\
\hline
\end{tabular}

the sampling period than sites 3, 4 and 5 (whose growth rate was higher and similar). The reforested stand (site 3) had the highest height increase of 10.5 $\mathrm{cm}$ over the two years (Fig 3a). There was greater height increment in year $1(\mathrm{p}<0.01)$ than in year $2(\mathrm{p}>0.05)$ during which there was no significant height increment.

Diameter increment was quite erratic and remained fairly uniform (see Fig 3b) during the sampling period except for the reforested stand

a

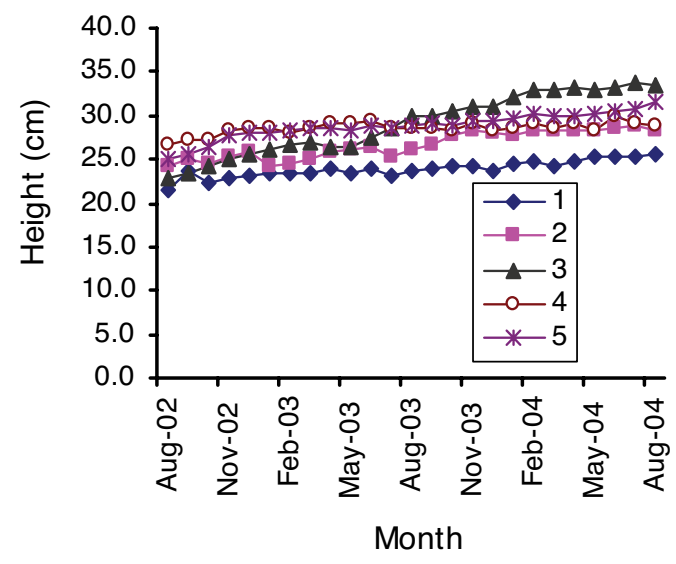

period, leaf and node counts were summed for each respective site for the last month. Sites in the western creek had a lower sum than those in the eastern creek, suggesting higher leaf emergence in the latter, corresponding with higher growth rates. The reforested stand had the lowest leaf loss as seen by the low number of nodes (Fig 4a-b). Leaf emergence rate in the reforested stand was intermediate i.e. between the above categories. The number of nodes among the two years significantly b

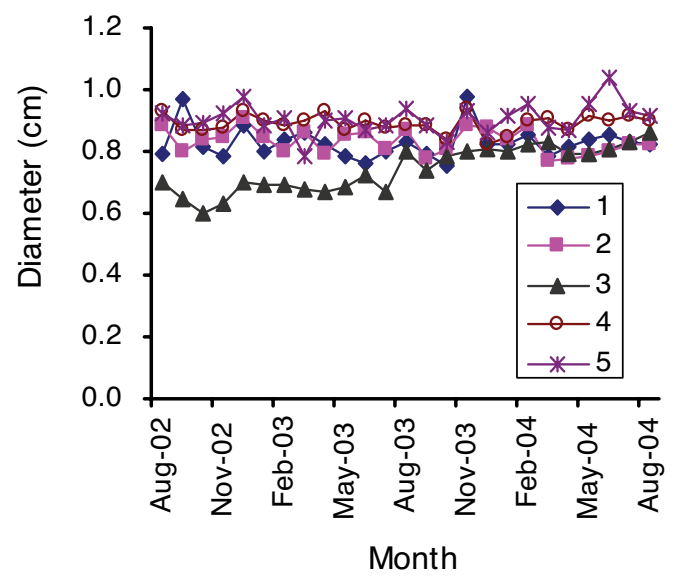

Fig 3. (a) Height increment and (b) Diameter variations in the five $C$. tagal sites over the sampling period 
a

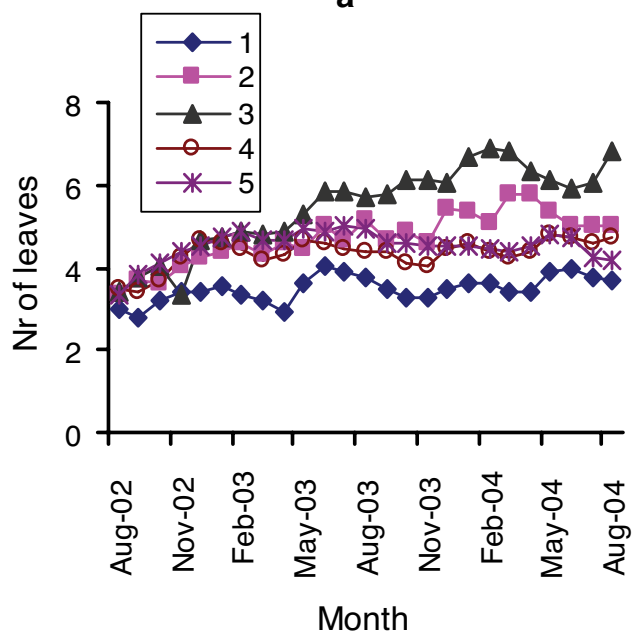

b

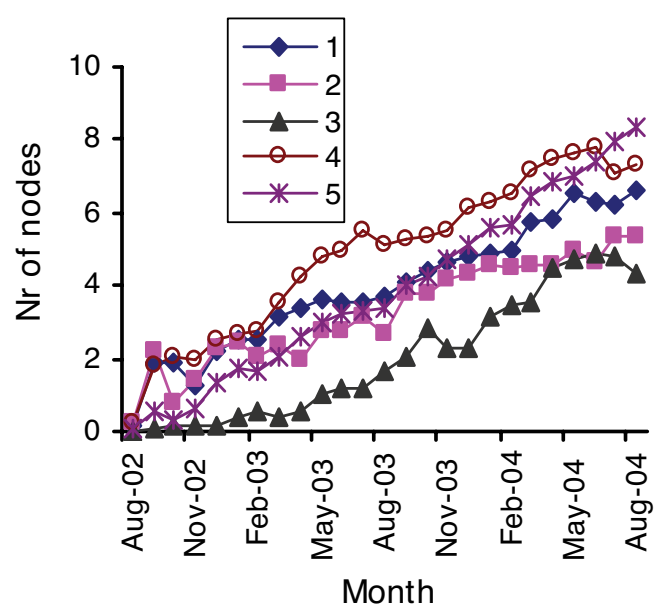

Fig 4. The mean number of (a) leaves and (b) nodes in the different $C$. tagal sites during the sampling period

varied due to the cumulative effect and continuous leaf loss.

\section{Environmental factors}

Environmental factors varied differently within and between both creeks. Overall, organic matter content was higher at the eastern creek $(\mathrm{p}<0.01)$. From the paired comparisons (Table 6), sites 4 and 5 (eastern creek) had the highest and similar organic matter content compared to all the other sites. The other sites also had similar organic matter content. There was a weak difference $(\mathrm{p}<$ $0.05)$ in moisture content between the two creeks with the eastern creek having the highest, due to site 4, which had the highest moisture content of all sites. All the other sites had similar moisture contents. Overall, the eastern creek had the highest percentage of fine sediments $(<65 \mu \mathrm{m})$. Site 1 had the lowest proportion of fine fractions, while site 4 had the highest. Site 3 and 4 had a similar proportion of the fine sediments. Among sites, site 1 had the highest PO43- concentration (17.7 $\pm 3.1 \mathrm{mg}$.at kg-1), which was however similar to the concentration in site 4 . The reforested stand had the lowest PO43- concentration Site 5 had the lowest $\mathrm{NH} 4+$ concentration, while the rest of the sites had similar values. The reforested stand (site 3) had the highest concentration of NO3-, while the western creek sites had similar NO3-levels, which were significantly higher than those at sites 4 and 5 . Site 4 and 5 had similar and higher salinity than the other sites. Height above datum (HAD) was greatest overall at the western creek sites (see

Table 6. Tukey's paired comparisons of sediment characteristics of the various sites. Significant differences are shown with asterix and/or in bold

\begin{tabular}{|c|c|c|c|c|c|c|c|c|c|}
\hline $\mathbf{i}$ & $\mathbf{j}$ & O/matter (\%) & Moisture (\%) & Fines $(\%)$ & $\mathrm{PO4}^{3-}$ & $\mathrm{NH}_{4}^{+}$ & $\mathrm{NO}_{3}^{-}$ & Salinity (\%o) & HAD (m) \\
\hline \multirow[t]{4}{*}{1} & 2 & $2.8 \pm 0.3$ & $25 \pm 1.2$ & $* 3.1 \pm 0.26$ & $* 8.2 \pm 1.3$ & $80 \pm 0.8$ & $10.7 \pm 0.9$ & $44 \pm 2$ & $2.5 \pm 0.03$ \\
\hline & 3 & $3.9 \pm 0.2$ & $27 \pm 0.5$ & $* 2.4 \pm 0.17$ & $* 4.8 \pm 0.3$ & $66 \pm 9.3$ & $* 19.8 \pm 0.8$ & $39 \pm 0.6$ & $* 2 \pm 0$ \\
\hline & 4 & $5.9 \pm 0.9$ & $* 34 \pm 1.8$ & $* 4.5 \pm 0.3$ & $14.8 \pm 1.9$ & $69 \pm 9.5$ & $* 7.1 \pm 1.7$ & $* 48 \pm 2.2$ & $* 2.7 \pm 0.01$ \\
\hline & 5 & $* 9.1 \pm 1.7$ & $26 \pm 1.4$ & $* 2.4 \pm 0.3$ & $* 6.6 \pm 1.4$ & $* 13 \pm 2.2$ & $* 2.4 \pm 0.5$ & $* 49 \pm 1$ & $* 2.3 \pm 0$ \\
\hline \multirow[t]{3}{*}{2} & $\begin{array}{l}1 \\
3\end{array}$ & $3.4 \pm 0.3$ & $24 \pm 1$ & $1.3 \pm 0.12$ & $17.7 \pm 3.1$ & $101 \pm 17.6$ & $\begin{array}{l}12.4 \pm 0.8 \\
*\end{array}$ & $42 \pm 1.2$ & $\begin{array}{l}2.6 \pm 0 \\
*\end{array}$ \\
\hline & 4 & & $*$ & $*$ & & & & & $*$ \\
\hline & 5 & $*$ & & & & $*$ & $*$ & & $*$ \\
\hline \multirow[t]{2}{*}{3} & 4 & & $*$ & $*$ & $*$ & & $*$ & $*$ & $*$ \\
\hline & 5 & $*$ & & & & $*$ & $*$ & $*$ & $*$ \\
\hline 4 & 5 & & $*$ & $*$ & $*$ & $*$ & $*$ & & $*$ \\
\hline
\end{tabular}


Table 6). Among the sites, 3 and 4 had the lowest HAD, while the western creek sites had similar HAD. A principal component analysis (PCA) of environmental factors clearly separated the sites (Fig 5) with sites 1 and 2 clustering together. An analysis of seedling growth over the two years as a function of the measured environmental factors showed a very weak interaction with HAD and canopy cover showing the highest correlation (among the other factors) of $30 \%$, which was still low.

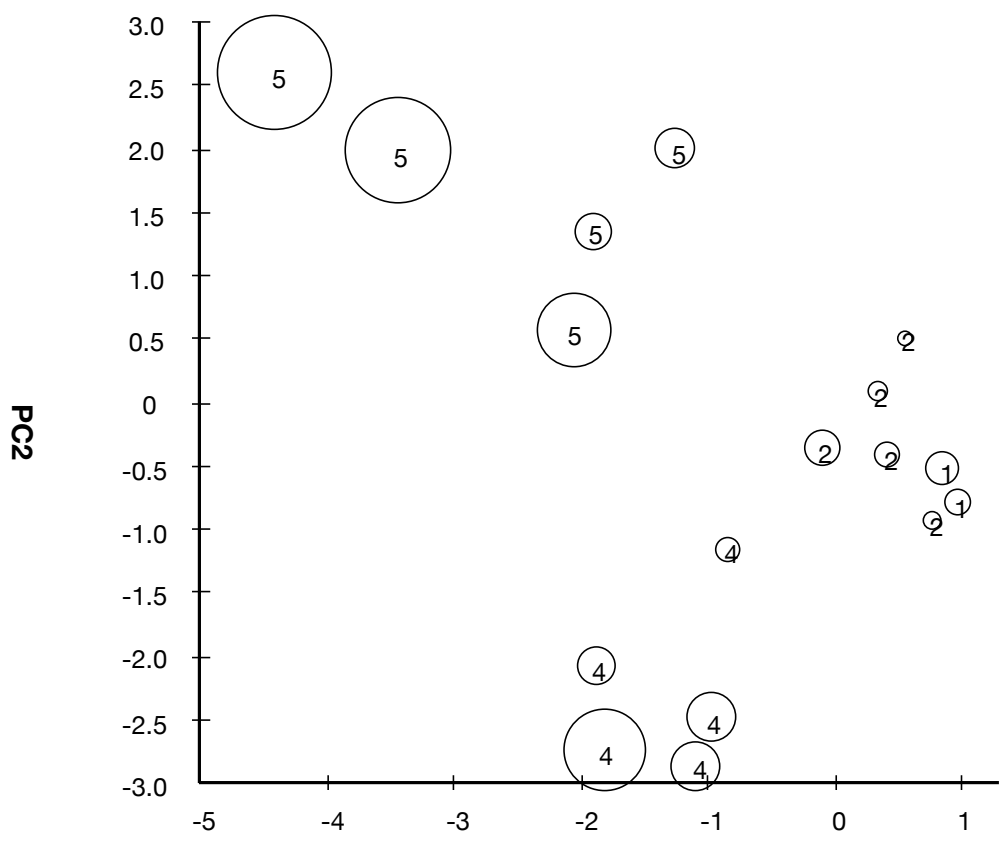

Fig 5. Principal component analysis (PCA) of environmental factors at the different $C$. tagal sites, with organic matter highlighted

\section{DISCUSSION AND CONCLUSION}

The reforested stand (site 3) had similar basal area as site 1 and its height was also similar to the western creek sites (1 and 2), while the eastern creek sites were more developed in terms of these structural attributes. The low structural growth of the western creek sites may be attributed to environmental stress. The eastern creek overall had higher proportion of fines and a lower HAD. The intertidal area of the western creek is also narrow (about $200 \mathrm{~m}$ wide) compared to the eastern creek with about $3 \mathrm{~km}$ length of intertidal area. On overall tidal energetics, the western creek could be erosional, while the eastern creek is depositional due to the low HAD of the latter and its wide intertidal area, suggesting a longer tidal residence time. The longer residence times could also facilitate more organic matter retention as shown by the higher organic matter content at this creek. The juvenile density assessed before the start of the demography experiment revealed that the western creek sites had the highest density (by an order of magnitude), followed by the eastern creek sites, while the reforested stand had the least density. Although the 
availability by canopy removal increased growth rates of Rhizophora mangle seedlings.

The two year demographic experiment was started after propagule establishment and thus the focus was on seedling growth and survival. During propagule establishment seedling survival is independent of light, nutrients or salinity because of the attached cotyledon (Clarke \& Myerscough, 1993), but other environmental factors e.g. hydrodynamics (Thampanya et al., 2002; Bosire $e t$ al., 2003), desiccation (Ball, 2002) and predation (Clarke \& Kerrigan, 2002; Osborne \& Smith, 1990) play a role. The monitoring started at the post-cotyledonary phase. In this phase, seedlings require a combination of light and edaphic resources (e.g. nutrients, favourable salinity) to support growth and survival (Clarke \& Allaway, 1993). These factors determine the size of the regeneration niche available (Clarke, 1995) and thus subsequent recruitment. The regeneration niche refers to the gap available and the attendant suite of environmental variables. Site 1 had the highest initial seedling density established but which reduced to the levels in sites 3 and 5 in four months due to the rapid initial mortality at this site. The suggested short tidal residence times would imply that the site is exposed to strong irradiance, which modifies edaphic factors subsequently limiting seedling survival (Ball, 2002). Tidal height, which determines the residence times and frequency of tidal inundation was the most significant factor influencing seedling growth. Expected high salinities in the western creek sites may have been ameliorated by tidal water since sampling was conducted immediately after high tide. Infrequent inundation of mangrove sediments affects the redox potential, changing from anaerobic to partially aerobic conditions during which phosphorous is adsorbed onto clay and complexes with calcium, magnesium and iron, limiting its availability (Saenger, 2002). Thus the high phosphorous concentration measured at the western creek sites may not be freely available for plant growth. Adult trees, especially at site 1, may thus be responding to compromised seedling survival conditions by producing copious propagules to counteract the expected high mortalities, as indicated by the high initial density of seedlings..
Generally the western creek sites had higher mortality of seedlings, lower leaf emergence rates, lower height and smaller diameter increment (growth) than the other sites. While the edaphic conditions do not sufficiently explain the varying seedling demography, it is likely that environmental cues play a critical role in limiting seedling performance in the western creek hence compromising seedling growth and survival. Soil redox potential and sulphide levels (not measured in this study) are among factors which have been found to influence mangrove seedling dynamics (Matthijs et al., 1999; McKee, 1993). Juvenile growth and allometry has been attributed to local differences in sediment accretion dynamics (Ellison \& Farnsworth, 1996); tidal cycles interacting with microtopography (Abdel-Razik, 1991) and the effects of irradiance and salinity (Ball \& Munns, 1992; Ball, 2002). The eastern creek had a gentle slope, a more extensive intertidal area and substrate of finer sediment, unlike the western creek sites which were generally sandy with a limited extent of the intertidal area. These factors emphasize differences in physical attributes of the two creeks, which may impact on mangrove growth. Modelling predicts that survivorship of seedlings is the main determinant of population growth rate (Burns \& Ogden, 1985), and when this is compromised, natural regeneration of the forest may be insufficient. The western creek forests are also adjacent to Gazi village, and thus easily accessible to the local people who are dependent on the mangroves. Anthropogenic pressure, as revealed by the many cut stumps, may be exerting more stress here than at the eastern creek sites and thus compromising natural regeneration and overall stand structure.

The reforested stand demonstrated height increments similar to those of the eastern creek natural stands. Canopy cover and HAD (though with a low correlation coefficient) were found to influence seedling growth most among the measured factors. The reforested stand was evenaged and had a high canopy cover suggesting competition for light by the understorey seedlings leading to more resource allocation to height increment and less to diameter. As a result the reforested stand had the greatest seedling height 
and least diameter increment over the two-year period (Fig $3 a \& b$ ). This may emphasize the need for silvicultural management of reforested sites by periodic thinning to open up the canopy to enhance overall stand development.

Mortality of seedlings was higher in year 1 than year 2, suggesting an inverse relationship between seedling densities and mortality. Overall, year 2 mortality was about $50 \%$ of year 1 mortality across sites, save for site 2 which had $8 \%$ at the end of year 2 , following a $53 \%$ mortality in year 1 . The probability that seedlings will recruit from one cycle to another, or into the next cohort, depends on the regeneration niche and subsequent environmental filtering (Clarke, 1995). Because of this annuallyvariable mortality rate, population growth may thus not be necessarily exponential or deterministic, but may have a non-linear component due to varying transition probabilities over time. Mortality rates differ with the age of the tree population and decreases as tree densities decrease.

Table 7. Basal areas and mean heights of $C$. tagal natural and reforested stands compared to other common mangrove species at Gazi (Source: Bosire et al 2003)

\begin{tabular}{llcc}
\hline Cover type & Species & BA $^{\mathbf{2}} \mathbf{h a}^{-\mathbf{1}}$ & Height (m) \\
\hline Natural & R. mucronata & 42 & 7.5 \\
& S. alba & 35 & 8.3 \\
& A. marina & 27 & 6.1 \\
\multirow{5}{*}{ Reforested } & C. tagal & 4.2 & 2.8 \\
& R. mucronata & 4.9 & 4.7 \\
& S. alba & 8.5 & 4.8 \\
& A. marina & 8 & 4.5 \\
& C. tagal & 2.7 & 2.2 \\
\hline
\end{tabular}

In terms of structural development of the four common mangrove species occurring at Gazi Bay (see Bosire et al., 2003), C. tagal has the least basal area and mean height compared to the other three species (Table 7). The growth of $C$. tagal species thus seems to be impaired at Gazi, probably because it is predominantly found in the higher intertidal, thus influenced by the tide only during spring tides. This creates desert-like conditions, which limit growth, as the plants invest more energy in surviving the harsh conditions. They may therefore require different management approaches as compared to the other species. The limited growth of this species has seen the reforested C. tagal stand "catch-up" with natural conspecific stands, contrary to findings on reforested stands of the other species (Bosire et al., 2003). As compared to the other reforested stands (Table 7), still the C. tagal plantation is the least structurally-developed, although they are all of the same age, emphasizing the limited structural growth of this species at Gazi. As to whether the C. tagal reforested stand will develop structurally more than the conspecific natural stands is a question for further study. Demographic studies should be conducted for period of at least 10 years to yield more useful information on the development of seedlings, and their eventual recruitment into the adult population. Such information is important for the formulation of mangrove management plans.

Acknowledgement-Much thanks to KMFRI colleagues: A. Obinga, G. Onduso and M. Orwenyi. This work was funded by WIOMSA grant \# 4/2003 and the International Foundation for Science (IFS) grants \# A/3223-1 and A/3223-2. The first author was a VUBAROS scholarship holder, while the last author was a Postdoctoral Researcher of the Fund for Scientific Research (FWO-Vlaanderen).

\section{REFERENCES}

Abdel-Razik S.M. (1991) Population structure and ecological performance of the mangrove Avicennia marina (Forssk.) Vierh. on the Arabian Gulf coast of Qatar. J Arid Environ 20: 331-338.

Ball, M.C. (2002) Interactive effects of salinity and irradiance on growth: implications for mangrove forest structure along salinity gradients. Trees 16: 126-139.

Ball, M.C. \& Munns, R (1992) Plant responses to salinity under elevated atmospheric concentrations of CO2. Aus. J Bot 40: 515-525.

Begon, H., Harper, J.L. \& Townsend CR (1996) Ecology: individuals, populations and communities 3rd ed. Blackwell Science. 1068 pp.

Bosire, J.O., Dahdouh-Guebas, F., Kairo, J.G. \& Koedam, N. (2003) Colonization of non-planted mangroves into reforested mangrove stands. Aquat Bot 76: 267-279.

Bosire, J.O., Dahdouh-Guebas, F., Kairo, J.G., Kazungu, J. \& Koedam N (2005) Propagule predation regulates natural regeneration in a highdensity reforested mangrove plantation. Mar Ecol Prog Ser 299: 157-166. 
Burns, B.R. \& Ogden, J. (1985) The demography of the temperate mangrove Avicennia marina (Forsk.) Vierh at its southern limit in New Zealand. Aust $J$ Ecol 10: 125 - 133.

Cintron, G. \& Schaeffer-Novelli, Y. (1984) Methods for studying mangrove structure. In: Snedaker SC, Snedaker JG (eds). The mangrove ecosystem: research methods. UNESCO, Paris, France, pp. 91-113.

Clarke, K.R. \& Gorley, R.N. (2001) Plymouth Routines In Multivariate Ecological Research (PRIMER) v5. PRIMER-E, UK.

Clarke, P.J. (1995) The population dynamics of the mangrove Avicennia marina: demographic synthesis and predictive modelling. Hydrobiologia 295: 83-88.

Clarke, P.J. \& Allaway, W.G. (1993) The regeneration niche of the grey mangrove Avicennia marina effects of salinity, light and sediment factors on establishment, growth and survival in the field. Oecologia 93:548-556.

Clarke, P.J. \& Kerrigan, R.A.. (2002) The effect of seed predators on the recruitment of mangroves. $J$ Ecol 90: 728-736.

Clarke, P.J. \& Myerscough, P.J. (1993) The intertidal distribution of the grey mangrove (Avicennia marina) in southeastern Australia: the effects of physical conditions, interspecific competition and predation on propagule establishment and survival. Aust J Ecol 18: 307-315.

Dahdouh-Guebas, F., Verneirt, M., Tack, J.F. \& Koedam, N. (1997) Food preferences of Neosarmatium meinerti de Man (Decapoda: Sesarminae) and its possible effect on the regeneration of mangroves. Hydrobiologia 347: 83-89.

Dahdouh-Guebas, F., Verneirt, M., Tack, J.F., Van Speybroeck, D. \& Koedam, N. (1998) Propagule predators in Kenyan mangroves and their possible effect on regeneration. Mar Freshw Res 49: 345350.

Dahdouh-Guebas, F., Mathenge, C., Kairo, J.G. \& Koedam N (2000) Utilization of mangrove wood products around Mida Creek (Kenya) amongst subsistence and commercial users. Econ Bot 54: 513-527.

Dahdouh-Guebas, F., Van Pottelbergh, I., Kairo, J.G., Cannicci, S. \& Koedam, N. (2004) Humanimpacted mangroves in Gazi (Kenya): predicting future vegetation based on retrospective remote sensing, social surveys, and tree distribution. Mar Ecol Prog Ser 272: 77-92.

Dahdouh-Guebas, F., Hettiarachchi, S., Lo Seen, D., Batelaan, O., Sooriyarachchi, S., Jayatissa, L.P. \& Koedam, N. (2005) Transitions in ancient inland freshwater resource management in Sri Lanka affect biota and human populations in and around coastal lagoons. Current Biology 15: 579-586

Dale, M.R.T. (1999) Spatial pattern analysis in plant ecology. Cambridge University Press, UK

Ellison, A.M., Farnsworth, E.J. (1993) Seedling survivorship, growth and response to disturbance in Belizean mangroves. American J Bot 80: 1137-1145

Ellison, A.M., Farnsworth, E.J. (1996) Spatial and temporal variability in growth of Rhizophora mangle saplings on coral cays: Links with variation in insolation, herbivory and local sedimentation rates. J Ecol 84: 717-731

Feller, I.C. \& McKee, K.L. (1999) Small gap creation in Belizean mangroves by a wood boring insect. Bitropica 31: 607-617

Greig-Smith, P. (1983) Quantitative Plant Ecology. 3rd edn. Studies in Ecology, 9. Blackwell Publishers, UK

Kairo, J.G. (1995). Community participatory forestry for rehabilitation of deforested mangrove areas of Gazi Bay (Kenya). "A First approach". Final technical report.

Kairo, J.G., Dahdouh-Guebas, F., Gwada, P.O., Ochieng, C., Koedam, N., (2002) Regeneration status of mangrove forests in Mida Creek, Kenya: a compromised or secured future? Ambio 31: $562-568$.

Lee, S.Y. (1998) Ecological role of grapsid crabs in mangrove ecosystems: a review. Mar Freshw Res 49: 335-343.

Matthijs, S., Tack, J., Van Speybroeck, D. \& Koedam, N. (1999) Mangrove species zonation and soil redox state, sulphide concentration and salinity in Gazi Bay (Kenya), a preliminary study. Mangroves and Salt Marshes 3: 243-249.

McKee, K.L. (1993) Soil physicochemical patterns and mangrove species distribution - reciprocal effects? J Ecol 81: 477-487.

Morisita, M., (1959) Measuring of the dispersion of individuals and analysis of the distribution patterns. Mem. Fac. Sci. Kyushu Univ. Ser. E Biol. 2: 215-235.

Osborne, K. \& Smith, T.J. III (1990) Differential predation on mangrove predation in open and closed canopy forest habitats. Vegetatio 89: 1-6.

Osunkonya, O.O. \& Creese, R.G. (1997) Population structure, spatial pattern and seedling establishment of the grey mangrove, Avicennia marina var. australasica, in New Zealand. Aust J Bot 45: 707-725.

Parsons, T.R., Maito, Y. \& Lalli, C.M. (1984) A manual of chemical and biological methods for seawater analysis. Pergamon Press, Oxford.

Pearson, T.R., Burslem, D.F., Goeriz, R.E. \& Dalling, J.W. (2003) Regeneration niche partitioning in 
neotropical pioneers: effects of gap size, seasonal drought and herbivory on growth and survival. Oecologia 137: 456-465.

Saenger, P. (2002) Mangrove ecology, silviculture and conservation. Kluwer.

Smith, T.J. (1987) Effects of light and intertidal position on seedling survival and growth in tropical tidal forests. J Exp Mar Bio Ecol 110: 133-146.

Srivastava, P.B.L. \& Bal, H.S. (1984) Composition and distribution pattern of natural regeneration after second thinning in Matang mangrove reserve,
Perak, Malaysia. Proc As Symp Mangr Env-Res \& Manag. p761-784.

Thampanya, U., Vermaat, J.E. \& Duarte, C.M. (2002) Colonisation success of common Thai mangrove species as a function of shelter from water movement. Mar Ecol Prog Ser 237: 111 -120.

UNEP(1998) East African Atlas of Coastal Resources, Kenya. UNEP, Kenya. 119p.

Watson, J.G. (1928) Mangrove forests of the Malay Peninsula. Fraser and Neave, Malay forest Records, 6. 